\title{
ANTIMICROBIAL AND ANTIOXIDANT PROPERTIES OF SIRMO (Allium vineale L.), MENDI (Chaerophyllum macropodum Boiss.) AND SIYABO (Ferula rigidula DC.)
}

\author{
Şenol Köse* , Elvan Ocak \\ Van Yuzuncu Yil University, Faculty of Engineering, Department of Food Engineering, Van, Turkey
}

Received / Geliş: 27.11.2017; Accepted / Kabul: 22.02.2018; Published online / Online bask1: 08.03.2018

Köse, S.., Ocak, E. (2018). Antimicrobial and antioxidant properties of sirmo (Allium vineale L.), mendi (Chaerophyllum macropodum Boiss.) and siyabo (Ferula rigidula DC.). GIDA (2018) 43 (2): 294-302 doi: 10.15237/gida.GD17099

\begin{abstract}
In the current study, antioxidative and antibacterial characteristics of the three various extracts such as methanol, ethanol and acetone of brine and fresh herbs containing Sirmo (Allium vineale L.), Mendi (Chaerophyllum macropodum Boiss.) and Siyabo (Ferula rigidula DC.) were investigated. When antioxidant activity was measured using the 2,2-difenil-1-picrylhydrazyl (DPPH) and 2,2'-azino-bis(3-ethylbenzothiazoline-6sulfonic acid) (ABTS) methods, the antimicrobial activity was measured by the agar well diffusion method. The DPPH values of all extracts ranged from $17.10 \pm 1.30$ to $119.53 \pm 0.06 \mathrm{mg}$ TEAC/ $\mathrm{kg}$ lyophilized herb, while ABTS values ranged from $53.55 \pm 3.49$ to $780.36 \pm 39.46 \mathrm{mg}$ TEAC $/ \mathrm{kg}$ lyophilized herb. It was determined that the exracts of Siyabo exhibited higher antibacterial activity in comparison to other plants. These results suggest that extracts of Sirmo, Mendi and Siyabo can be used as natural antimicrobials and antioxidants in food processing.
\end{abstract}

Keywords: Antimicrobial activity, antioxidant activity, fresh and brine herbs

\section{SİRMO (Allium vineale L.), MENDİ (Chaerophyllum macropodum Boiss.) VE SIYYABO (Ferula rigidula DC.)'NUN ANTİMİKROBIYYAL VE ANTİOKSİDAN ÖZELLİKLERİ}

ÖZ

Bu çalışmada, salamura ve taze Sirmo, Mendi ve Siyabo otlarının metanol, etanol ve aseton ekstraktlarının antioksidan ve antibakteriyel özellikleri araştırılmıştır. Ekstraktların antioksidan aktiviteleri DPPH ve ABTS yöntemleri ile belirlenirken antimikrobiyel aktiviteleri agar kuyu difüzyon metodu ile belirlenmiștir. Tüm ekstraktların ABTS değerleri $53.55 \pm 3.49$ ile $780.36 \pm 39.46 \mathrm{mg}$ TEAC $/ \mathrm{kg}$ dondurarak kurutulmuş ot arasında değişirken, DPPH değerleri ise $17.10 \pm 1.30$ ile $119.53 \pm 0.06 \mathrm{mg}$ TEAC $/ \mathrm{kg}$ dondurarak kurutulmuş ot olarak saptanmıştır. Siyabo ekstraktlarının diğer bitkilere kıyasla daha yüksek antibakteriyel aktivite gösterdiği tespit edilmiştir. Bu sonuçlar Sirmo, Mendi ve Siyabo ekstraktlarının gıda işlemede doğal antimikrobiyeller ve antioksidanlar olarak kullanılabileceğini göstermektedir.

Anahtar kelimeler: Antimikrobiyel aktivite, antioksidan aktivite, taze ve salamura otlar

${ }^{*}$ Corresponding author / Yazışmalardan sorumlu yazar

$\square$ senolkose28@gmail.com, ○(+90) 432225 1024, 鸟 (+90) 4322251730 


\section{INTRODUCTION}

It has been well known that plant spices have antimicrobial (Durmaz et al., 2006) and antioxidant activity since ancient times (Delaquis et al., 2002). In recent times, there is an increasing tendency in the antioxidant and antimicrobial role of vegetables, fruits, teas, wines, seeds and medicinal plants, that can be used as natural substances of antimicrobial and antioxidants (Dillard and German, 2000). The phenolic compounds in natural materials such as medicinal herbs, spices and plants has begun to gain more and more attention due to their antioxidant and antimicrobial activities (Cai et al., 2004; Dağdelen et al., 2014).

Especially in eastern Anatolia region of Turkey, Sirmo (Allium vineale L.), Mendi (Chaerophyllum macropodum Boiss.) and Siyabo (Ferula rigidula DC.) are traditionally used in production of herbed cheese for their flavor and aroma (Ocak et al., 2015; Köse, 2015). They are usually collected from mountains in May and June and are added into the cheeses with two ways. Firstly, the herbs are used freshly after washing and cutting into small pieces. The second way is making pickle from herbs. Approximately 30 days later, they are ready to produce herby cheese. They can also be stored for one year at ambient temperature and these herbs can be used whenever needed (Kavaz et al., 2013).

The chemical, microbiological, antimicrobial and antioxidant characteristics of some herbs used in the production of Herby cheese were investigated by several authors (Akyüz et al., 1996; Ağaoğlu et al., 2005; Sağun et al., 2005; Durmaz et al., 2006; Sağun et al., 2006; Çoruh et al., 2007; Çelik et al., 2008; Dağdelen, 2010; Dağdelen et al., 2014; Durmaz et al., 2015) However, in the reported studies, the effects of brine treatments on antioxidant and antimicrobial activity of herbs haven't been reported. Therefore, there is a need to examine the antimicrobial and antioxidant properties of herbs to compare treatments (fresh and brine), ensure product safety and produce high quality herby cheese.
The aim of this study was to evaluate in vitro antioxidant and antibacterial properties of methanol, ethanol and acetone extracts of fresh and brined Sirmo, Mendi and Siyabo.

\section{MATERIALS AND METHODS}

\section{Herbs and preparation of extracts}

The investigation material consists of three local herbs such as Sirmo (Allium vineale L.), Mendi (Chaerophyllum macropodum Boiss.) and Siyabo (Ferula rigidula DC.) were used. These herbs are grown in Van province of Turkey.

The herbs were collected from mountain by villagers based on their own experiences and fresh herbs were sold in local markets. Samples were first washed with deionised water and then cut into small pieces. After that each herb was divided into two portions; the first portion (containing $20 \%$ whey in $10 \%$ brine) kept at $4{ }^{\circ} \mathrm{C}$ for one month and the second portion was placed in a freeze-drying device (Freeze-drier, Labconco, Czech Republic, Model:117) after being subjected to freezing at $-18{ }^{\circ} \mathrm{C}$ (freezer) for 12 hours. One month later, brine herbs were subjected to freze drying like fresh herbs.

Methanol, ethanol and acetone solvents were used to obtain extracts from herbs for antimicrobial activity tests. About $1.25 \mathrm{~g}$ of grounded lyophilized brine and fresh herbs were extracted individually with solvents by using Soxhlet extractor for $6 \mathrm{~h}$ at the boiling point of the solvents (Lin et al.,1999). The solvents (methanol, ethanol and acetone) were concentrated using a vacuum rotary evaporator (IKA RV 10 rotary evaporator, Germany) and the final volume was dissolved in dimethyl sulfoxide (DMSO), then extracts were filtered using (Whatman no:1) filter paper and completed in 25 $\mathrm{ml}$ with DMSO. These stock solutions were kept at $-18{ }^{\circ} \mathrm{C}$ until used.

For total phenolics and antioxidant activity extracts, $2.5 \mathrm{~g}$ of grounded lyophilized herb was put into a centrifuge tube, stirred with $22.5 \mathrm{~mL}$ of methanol and shaken in an incubator (Heidolph Unimax 1010, Germany) for $2 \mathrm{~h}$ in dark at $20^{\circ} \mathrm{C}$. After this, the homogenate was centrifuged at 
9000 x g (Hettich Zentrifugen Universal 32 R, Germany) for $10 \mathrm{~min}$ at $20{ }^{\circ} \mathrm{C}$ and then supernatant was transferred into labeled sterile screw capped bottles. The above procedure was repeated twice using the pellet and then collected supernatants were combined. The supernatants were concentrated using a vacuum rotary evaporator (IKA RV 10, Germany) at $40{ }^{\circ} \mathrm{C}$. The same procedure was repeated for ethanol and acetone extracts. Then residue was dissolved in 2 $\mathrm{mL}$ DMSO and the final volume was completed to $25 \mathrm{~mL}$ with methanol.

\section{Bacterial cultures}

Three Gram positive bacteria (Staphylococcus aureus ATCC 29213, Bacillus cereus ATCC 11778, Enterococcus faecalis ATCC 33186) and four Gram negative bacteria (Escherichia coli ATCC 11303, Salmonella typhimurium ATCC 13311, Pseudomonas aeruginosa ATCC 19429, Yersinia enterocolitica ATCC 27729) were used in this study. Bacterial cultures were stored on Müeller Hinton Agar (Oxoid) at $+4{ }^{\circ} \mathrm{C}$ until use.

\section{Antibacterial assay}

An agar well diffusion method was used to determine the antibacterial activities of herb species (NCCLS, 1999). $50 \mathrm{mg} / \mathrm{mL}$ concentrations of all the extracts in DMSO solvents were used and sterilized by filtration (pore size $0.47 \mathrm{~mm}$ ). All the microorganisms mentioned above were incubated at $37 \pm 0.1^{\circ} \mathrm{C}$ for $24 \mathrm{~h}$ after inoculation into Mueller Hinton Broth (Oxoid). After the incubation, bacterial inoculum was diluted with sterile physiological solution with $0.5 \mathrm{Mc}$ Farland turbidity standard tubes. MuellerHinton Agar was inoculated by $100 \mu \mathrm{L}$ of prepared culture over the entire agar surface. One hundred microliters of extract solution was filled into the wells of agar plates directly. The plates were kept at $20-25^{\circ} \mathrm{C}$ for $2 \mathrm{~h}$ to enable diffusion of extracts and were incubated for $24 \mathrm{~h}$ at $37^{\circ} \mathrm{C}$ for all bacterial species. Standard antibiotic discs ( $6 \mathrm{~mm}$ in diameter) of Tetracycline $(30 \mu \mathrm{g})$ and Ampicillin $(10 \mu \mathrm{g})$ were used as positive controls for comparison. Methanol, ethanol, acetone and DMSO solvents were also tested as negative controls.
Antibacterial activity of the extracts were evaluated by measuring the inhibition zone against tested organisms. Each assay was performed in triplicate.

\section{Determination of total phenolic compounds}

The total phenolic content of extracts were analysed by the Folin-Ciocalteu method (Yemiş et al., 2008). A total of $150 \mu \mathrm{L}$ sample extract and $3.0 \mathrm{~mL}$ (of $2 \%$ ) sodium carbonate ( $\mathrm{w} / \mathrm{v}$ in water) were transferred into a test tube. After about two minutes $150 \mu \mathrm{L}$ Folin-Ciocalteu's reagent (1:1, $\mathrm{v} / \mathrm{v}$ in water) was added and mixed throughly. The reaction was kept in the dark for $45 \mathrm{~min}$ at room temperature. The absorbance values of the mixture was recorded at $765 \mathrm{~nm}$ in a spectrophotometer (UV Mini-1240, Shimadzu, Japan). Each assay was performed in triplicate. Gallic acid was used to calculate calibration curve and the results were expressed as $\mathrm{mg}$ of gallic acid equivalents per $\mathrm{kg}$ of lyophilized herb ( $\mathrm{mg}$ $\mathrm{GAE} / \mathrm{kg}$ of lyophilized herb ).

\section{Antioxidant activity DPPH assay}

The free radical scavenging activity of the extracts of various herb species were measured using DPPH - free radical scavenging method (BrandWilliams et al., 1995) with slight modifications. $100 \mu \mathrm{l}$ of the herb extract were added to $2.4 \mathrm{~mL}$ of DPPH solution (25 mg DPPH/L methanol). The mixture was shaken vigorously and maintained in dark for $30 \mathrm{~min}$. After the incubation, the absorbance of resulting solution was recorded at $520 \mathrm{~nm}$ in a spectrophotometer. Results were expressed as mg Trolox (SigmaAldrich, Canada) equivalent antioxidant capacity (TEAC) per kg of lyophilized herb. Methanol was used instead of the sample for the control measurements.

\section{ABTS assay}

ABTS (Sigma-Aldrich, Canada) radical cation solution was prepared by reacting $7.0 \mathrm{mM}$ ABTS stock solution with $2.45 \mathrm{mM}$ (final concentration) potassium persulfate for $16 \mathrm{~h}$ in the dark at room temperature until reaching a stable oxidative state (Re et al. 1999). Then the ABTS ${ }^{\bullet+}$ solution was diluted with methanol to get an absorbance of 
$0.700 \pm 0.020$ at $734 \mathrm{~nm}$. For the spectrophotometric assay, a diluted solution of $\mathrm{ABTS}^{+}(2.9 \mathrm{~mL})$ and $100 \mathrm{~mL}$ of herb extract in methanol was mixed thoroughly and the absorbance was determined at $734 \mathrm{~nm}$ at $6 \mathrm{~min}$ after mixing. Results were expressed in terms of mg TEAC per kg lyophilized herb.

\section{Statistical analysis}

Data were recorded as means \pm standard deviation of triplicate measurements. SAS version 9.3 (SAS, 2012) was used to analyse statistical calculations. Duncan multiple comparison test was performed on herb species and the effect of main treatments was determined. Statistical differences were considered significant at $P$ $<0.05$.

\section{RESULTS AND DISCUSSION Antimicrobial activity}

Table 1 shows the results of the antimicrobial activity of plant extracts. The inhibition zones varied depending on the nature of solvent, plant species, treatments of plant species used for extraction and bacterial species.

Table 1. Antibacterial activities of herb extracts obtained using different herb species and solvents

\begin{tabular}{|c|c|c|c|c|c|c|c|c|c|}
\hline \multirow{2}{*}{$\begin{array}{l}\text { Plant } \\
\text { species }\end{array}$} & \multirow{2}{*}{ Treatments } & \multirow{2}{*}{ Extracts } & \multicolumn{7}{|c|}{ İnhibiton zone diameter $(\mathrm{mm})$} \\
\hline & & & $\mathrm{Sa}$ & $\mathrm{Bc}$ & Ef & Ec & $\mathrm{St}$ & $\mathrm{Pa}$ & $\mathrm{Ye}$ \\
\hline \multirow{6}{*}{ Sirmo } & \multirow{3}{*}{ Fresh } & Methanol & 19 & 15 & - & 14.50 & - & 12.50 & 10.50 \\
\hline & & Ethanol & 16 & 10 & - & 9.50 & - & 17 & 15.25 \\
\hline & & Acetone & 13 & 7 & - & 7.50 & - & 13.50 & 8.25 \\
\hline & \multirow{3}{*}{ Brine } & Methanol & 19.50 & 17 & 8.25 & 19 & - & 17 & 13.50 \\
\hline & & Ethanol & 16.50 & 13 & 7 & 14.25 & - & 18 & 18.50 \\
\hline & & Acetone & 13.50 & 9 & - & 12.50 & - & 17.25 & 11.50 \\
\hline \multirow{6}{*}{ Mendi } & \multirow{3}{*}{ Fresh } & Methanol & 18 & 13 & - & 13.25 & - & 18.50 & - \\
\hline & & Ethanol & 16 & 8 & - & 11.50 & - & 20 & 7.50 \\
\hline & & Acetone & 12 & - & - & 8.50 & - & 12 & - \\
\hline & \multirow{3}{*}{ Brine } & Methanol & 18.50 & 16 & - & 18 & - & 16.25 & 8.50 \\
\hline & & Ethanol & 16.25 & 11 & - & 17.50 & - & 20 & 10.75 \\
\hline & & Acetone & 13 & 8 & - & 13.50 & - & 13.25 & 7.25 \\
\hline \multirow{6}{*}{ Siyabo } & \multirow{3}{*}{ Fresh } & Methanol & 21 & 17 & - & 13.50 & - & 20.50 & 9.50 \\
\hline & & Ethanol & 19.50 & 12 & - & 18 & - & 19 & 11 \\
\hline & & Acetone & 18.50 & 8 & - & 11.50 & - & 15.25 & 7.50 \\
\hline & \multirow{3}{*}{ Brine } & Methanol & 23.50 & 19 & 10.50 & 20 & 7 & 17.25 & 12.50 \\
\hline & & Ethanol & 21 & 14 & 7.75 & 21 & 9.25 & 19.50 & 14 \\
\hline & & Acetone & 21 & 10 & - & 18 & - & 14.25 & 10.50 \\
\hline \multicolumn{10}{|c|}{ Positive controls } \\
\hline \multicolumn{3}{|c|}{ Tetracycline $(30 \mu \mathrm{g})$} & 40 & 23 & 20 & 20 & 21 & 10 & 28 \\
\hline \multicolumn{3}{|c|}{ Ampicillin $(10 \mu \mathrm{g})$} & 30 & 10.50 & 27 & 21 & 24 & - & 12 \\
\hline \multicolumn{10}{|c|}{ Negative controls } \\
\hline \multicolumn{3}{|c|}{ Methanol } & - & - & - & - & - & - & - \\
\hline \multicolumn{3}{|c|}{ Ethanol } & - & - & - & - & - & - & - \\
\hline \multicolumn{3}{|c|}{ Acetone } & - & - & - & - & - & - & - \\
\hline \multicolumn{3}{|l|}{ DMSO } & - & - & - & - & - & - & - \\
\hline
\end{tabular}

Bacteria: Sa, Staphylococcus aureus; Bc, Bacillus cereus; Ef, Enterococcus faecalis; Ec, Escherichia coli; St, Salmonella typhimurium; Pa, Pseudomonas aeruginosa; Ye, Yersinia enterocolitica

-: No inhibition zone. 
In general, methanol extracts of the three species were found to be more efficient than other extracts on Gram positive and negative bacterias. These results are in accordance with those from previous studies of plants for antimicrobial activity, where it was reported that methanol is a good solvent for extraction of antibacterial substances from plants in comparison with other solvents (Ahmad et al., 1998; Eloff et al., 1998; Ojala et al., 2000).

Methanol extracts of brine Siyabo showed the largest inhibition zone against $S$. aureus $(23.50$ $\mathrm{mm}$ ). The fact that methanol extract of Siyabo has higher antibacterial activity may be due to the high content of phenolics in this plant (Table 2).

Sirmo and Siyabo extracts had weak antibacterial activity and Mendi extracts didn't have any antibacterial activity on E. faecalis. Also, Siyabo extracts had weak antibacterial activity, Sirmo and Mendi didn't have any antibacterial activity on S.typhimurium.

All of fresh and brine herb extracts showed higher antibacterial activity than reference antibiotics against $P$. aeruginosa. Therefore, extracts from these plants could be used as natural food preservatives, which could inhibit growth of $P$. aeruginosa. Solvents (negative control) used for extraction showed no activity against any bacteria tested.

Brine Siyabo extracts had higher antibacterial activity than Sirmo and Mendi extracts against both Gram positive and negative bacterias. The higher antibacterial activity of this extract may be due to the higher terpenes of this plant. The most abundant terpenes in Siyabo are a-terpinene, apinene, L-limonene (Dağdelen, 2014) and these compounds have been reported to antibacterial ability (Griffin et al., 1999).

\section{Total phenolic compounds and radical- scavenging activities}

Total phenolic compounds of various solvent extracts were shown in Table 2. Total phenolics of herb species ranged from $14.99 \pm 0.86$ to 164.20 $\pm 3.44 \mathrm{mg} \mathrm{GAE} / \mathrm{kg}$ lyophilized herb. While methanol extract of fresh Siyabo had the highest total phenolic, acetone extract of brine Mendi had the lowest total phenolic.

Table 2. Total phenolic compounds ( $\mathrm{mg}$ of GAE/kg lyophilized herb) of herb extracts obtained using different herb species and solvents

\begin{tabular}{|c|c|c|c|c|}
\hline & \multirow{2}{*}{ Solvents } & \multicolumn{3}{|c|}{ Herb species } \\
\hline & & Sirmo & Mendi & Siyabo \\
\hline \multirow{4}{*}{ Fresh } & Methanol & $89.99 \pm 4.65^{\mathrm{aB}}$ & $101.50 \pm 6.29 \mathrm{aB}$ & $164.20 \pm 3.44^{\mathrm{aA}}$ \\
\hline & Ethanol & $42.36 \pm 3.37 \mathrm{bB}$ & $32.21 \pm 0.98^{\mathrm{bC}}$ & $100.24 \pm 4.25^{\mathrm{bA}}$ \\
\hline & Acetone & $33.52 \pm 1.33^{\mathrm{bB}}$ & $23.26 \pm 1.25^{\mathrm{bC}}$ & $52.75 \pm 2.58^{\mathrm{cA}}$ \\
\hline & $\begin{array}{l}\text { General } \\
\text { Average }\end{array}$ & $55.29 \pm 27.29^{\mathrm{aB}}$ & $52.32 \pm 38.41^{\mathrm{aB}}$ & $105.73 \pm 50.09^{\mathrm{aA}}$ \\
\hline \multirow{4}{*}{ Brine } & Methanol & $90.79 \pm 0.47 \mathrm{aB}$ & $38.77 \pm 1.13^{\mathrm{aC}}$ & $141.19 \pm 5.23^{\mathrm{aA}}$ \\
\hline & Ethanol & $35.22 \pm 1.41^{\mathrm{bB}}$ & $28.23 \pm 0.52^{\mathrm{bC}}$ & $58.19 \pm 1.62^{\mathrm{bA}}$ \\
\hline & Acetone & $25.00 \pm 1.41^{\mathrm{cB}}$ & $14.99 \pm 0.86^{\mathrm{cC}}$ & $30.00 \pm 1.49 \mathrm{cA}$ \\
\hline & $\begin{array}{l}\text { General } \\
\text { Average }\end{array}$ & $50.34 \pm 31.68 \mathrm{aAB}$ & $27.33 \pm 10.68^{\mathrm{aB}}$ & $76.46 \pm 51.77 \mathrm{aA}$ \\
\hline
\end{tabular}

Data values are expressed as means \pm standard deviation,

Values in the same column followed by adifferent letters (a-c) are significantly different $(P<0.05)$, Values in the same row followed by adifferent letters $(A-C)$ are significantly different $(P<0.05)$, General averages were also evaluated between themselves $(P<0.05)$. 
The amounts of total phenolics found in the methanol extracts were at very high concentrations in comparison to other solvents. These results are in accordance with those from previous literature (Arabshahi-Delouee and Urooj, 2007; Dağdelen et al., 2014). Total phenolic compounds in the methanol extracts ranged from 38.77 (in Mendi) to 164.20 (in Siyabo) $\mathrm{mg}$ of GAE/kg lyophilized herb.

The average total phenolic content of fresh herbs were found to be higher than brined samples of herbs. Similarly, Durmaz et al. (2015) reported that dried Sirmo and Mendi herbs contain higher levels of total phenolics than that in brined samples of the herbs.

According to the findings obtained from the herb extracts, total phenolic compounds were found to be lower than some dried fruits (apple, peach, quince, orange, grapefruit, kiwi, banana, cantaloupe, watermelon, strawberries and tomatoes) (Ertekin Filiz and Seydim, 2014) and some vegetables (mint, eruca sativa, lepidium sativum, rumex acetosa, portulaca oleracea, dill, chicory, and parsley) (Barut Uyar et al., 2013).
Both DPPH and ABTS assays are widely used for evaluating antioxidant activities of natural extracts (Dağdelen et al., 2014). Antioxidant activities of different extracts expressed as $\mathrm{mg}$ TEAC $/ \mathrm{kg}$ lyophilized herb (Table 3 and 4).

Antioxidant activity ranged from 17.10 to 120.21 mg TEAC equivalents/ kg lyophilized herb weight and ethanol extract of fresh Siyabo exhibited the highest antioxidant activity (120.21 mg TEAC $/ \mathrm{kg}$ lyophilized herb), followed by methanol extract of fresh Siyabo (118.36 mg TEAC/kg lyophilized herb) with the DPPH method. Similarly, it was determined that the ethanol extract of Siyabo gave the highest results among the solvents used by Dağdelen et al., (2010).

DPPH relatively stable organic radical, has been widely used in the determination of antioxidant activity of single compounds, as well as of various herb extracts (Katalinic et al., 2006). Antioxidant activity determined by ABTS showed the same relationships as did DPPH method, but TEAC values were higher.

Table 3. Antioxidant activities of herb extracts obtained using different herb species and solvents determined by the DPPH methods (mg TEAC/kg lyophilized herb)

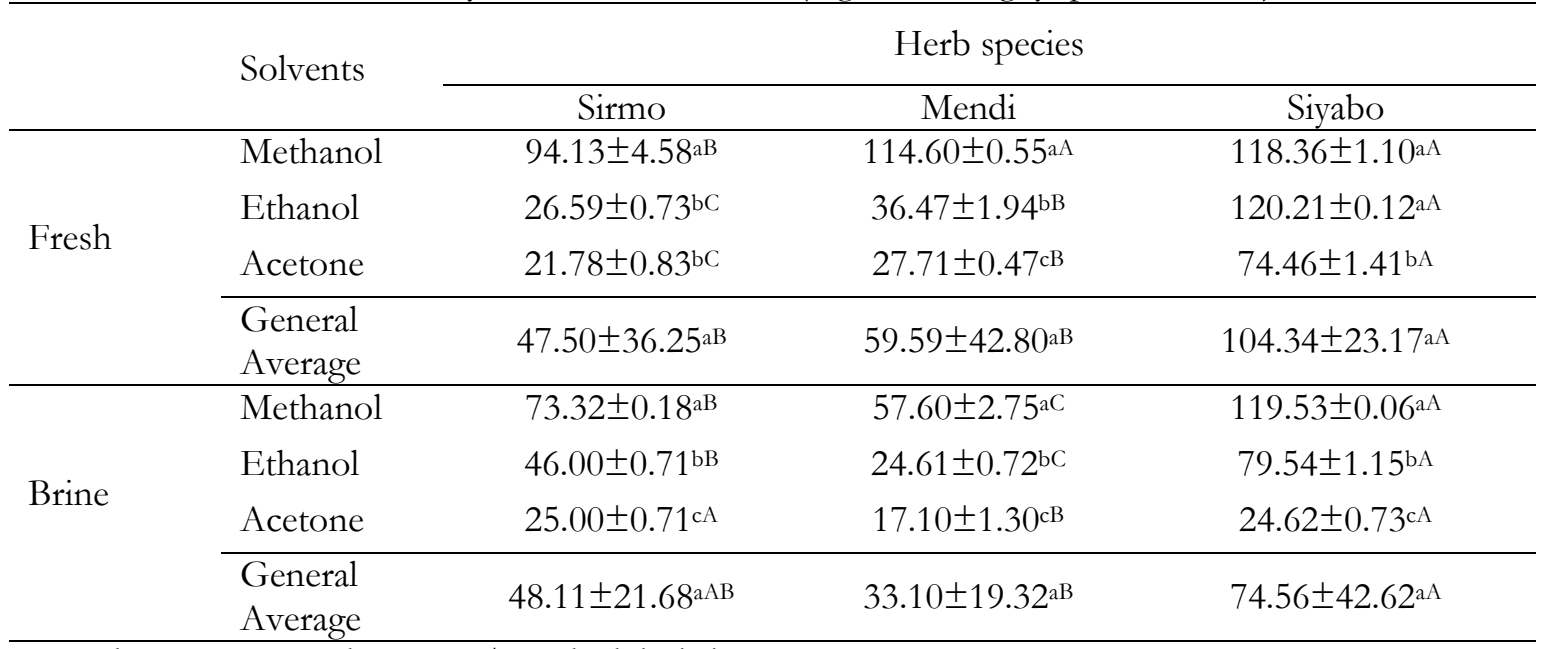

Data values are expressed as means \pm standard deviation,

Values in the same column followed by a different letters (a-c) are significantly different $(P<0.05)$, Values in the same row followed by a different letters $(A-C)$ are significantly different $(P<0.05)$, General averages were also evaluated between themselves $(P<0.05)$. 
Table 4. Antioxidant activities of herb extracts obtained using different herb species and solvents determined by the ABTS methods (mg TEAC/kg lyophilized herb)

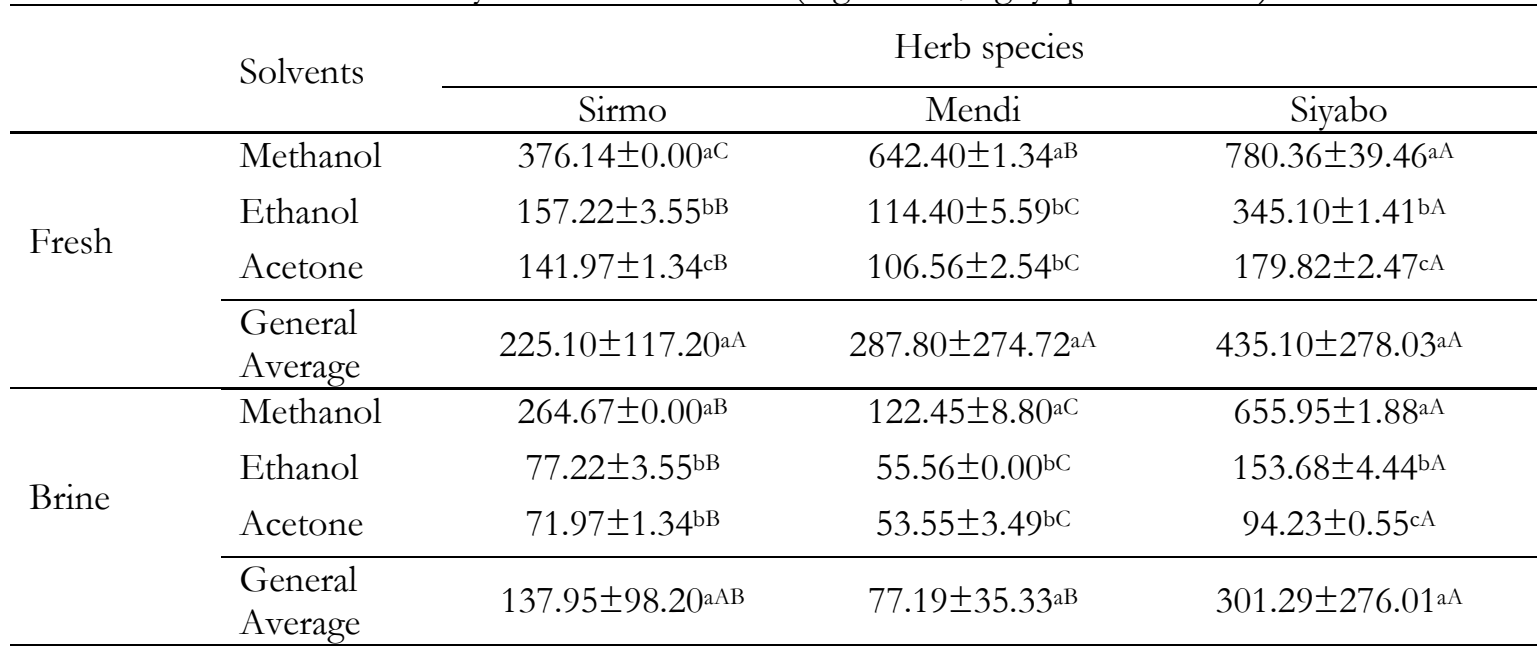

Data values are expressed as means $\underline{ \pm}$ standard deviation,

Values in the same column followed by a different letters (a-c) are significantly different $(P<0.05)$, Values in the same row followed by a different letters $(\mathrm{A}-\mathrm{C})$ are significantly different $(P<0.05)$, General averages were also evaluated between themselves $(P<0.05)$.

Antioxidant activity values of herb varieties ranged from 53.55 to $780.36 \mathrm{mg}$ TEAC $/ \mathrm{kg}$ lyophilized herb with the ABTS method. Methanol extract of fresh Siyabo antioxidant activity determined according to this method, showed the highest antioxidant concentration (780.36 mg TEAC/kg lyophilized herb).

Differences in antioxidant activity between the investigated herbs may be due to the variation in antioxidant species as well as polarity and solubility behaviors. Phenolic compounds are the major components responsible for the antioxidant activity of herbs (Rice-Evans et al., 1996).

According to the findings obtained from the herb extracts, DPPH and ABTS values were found to be lower than leaf and flower extracts of $A$. roseum (Najja et al. 2011). In another study, Çoruh et al. (2007) studied antioxidant capacity of $C$. macropodum from Van province in Turkey and found that $50 \%$ inhibitory concentration (IC50) values were 0.623 and $0.852 \mathrm{mg} / \mathrm{mL}$ for $\mathrm{DPPH}$ radical scavenging and lipid peroxidation inhibition, respectively. Antioxidant activities of the leaves and flowers extracts of C. macropodum from Isfahan province in Iran were found 196.8 and $167.1 \mu \mathrm{g} / \mathrm{mL}$ as IC50 values for DPPH test from Ebrahimabadi et al. (2010), respectively. The antioxidant activities of $C$. macropodum obtained from these studies cannot be compared with those obtained from our study because their values given in different units.

\section{CONCLUSION}

As a result, utilization of methanol and ethanol play a vital role in the extraction of plant constituents. Therefore, the total phenolic compounds, antibacterial and antioxidant activity found in the methanol and ethanol extracts of herbs were determined as very high in comparison to acetone extracts.

Studied extracts of herbs had antibacterial activity against Gram positive and negative bacterias. Antibacterial ability of the extracts might depend on their some phenolics and other bioactive components. This investigation is first study on the antibacterial and antioxidant activity of fresh and brine herbs studied. The compounds responsible for the antimicrobial and antioxidant ability are still unclear. Therefore, further phytochemical investigations are needed to determine, isolate and characterize the bioactive components. 


\section{ACKNOWLEDGMENTS}

This work was supported as financial by Coordination Unit of Scientific Research Projects of Yuzuncu Yil University (Project Number: BAP-2012-FBE-D057).

\section{REFERENCES}

Ağaoğlu, S., Dostbil, N., Alemdar, S. 2005. The antibacterial efficiency of some herbs used in Herby Cheese. YYÜ Vet Fak Derg, 16(2):39-41.

Ahmad, I., Mehmood, Z., Mohammad, F. 1998. Screening of some Indian medicinal plants for their antimicrobial properties. I Ethnopharmacol, 62, 183-193.

Akyüz, N., Coşkun, H., Andiç, S., Altun, İ. 1996. Some general characteristics ofpickled herbs used in making Van herby cheese. YYÜ Ziraat Fakültesi Dergisi, 6(1): 35-41.

Arabshahi-Delouee, S., Urooj, A. 2007. Antioxidant properties of various solvent extracts of mulberry (Morus indica L.) leaves. Food Chem, 102: 1233-1240.

Barut Uyar, B., Gezmen-Karadağ, M., Şanlıer, N., Günyel, S. 2013. Toplumumuzda siklikla kullanilan bazı bitkilerin toplam fenolik madde miktarlarının saptanması. GID A, 38(1): 23-29.

Brand-Williams, W., Cuvelier, M.E., Berset, C. 1995. Use of a free radical method to evaluate antioxidant activity. LWT-Food Sci Technol, 28 (1): 25-30.

Cai, Y.Z., Luo, Q., Sun, M., Corke, H. 2004. Antioxidant activity and phenolic compounds of 112 traditional Chinese medicinal plants associated with anticancer. Life Sciences, 74:21572184.

Çelik, S.E., Özyürek, M., Altun, M., Bektaşoğlu, B., Güçlü, K., Berker, I., Özgökçe, F., Apak, R. 2008. Antioxidant capacities of herbal plants used in the manufacture of Van herby cheese: "Otlu Peynir”. Int J Food Prop, 11: 747-761.

Çoruh, N., Sağdiçoğlu Celep, A. G., Özgökçe, F. 2007. Antioxidant properties of Prangos ferulacea (L.) Lindl., Chaerophyllum macropodum Boiss. and Heracleum persicum Desf. from Apiaceae family used as food in Eastern Anatolia and their inhibitory effects on glutathione-S-transferase. Food Chem, 100: $1237-1242$.

Dağdelen, Ş. 2010. Otlu Peynire Katılan Önemli Ot Türlerinin Antimikrobiyal, Antioksidan Etkileri, Aroma Profili ve Bazı Kimyasal Özelliklerinin Belirlenmesi. İnönü Üniversitesi Fen Bilimleri Enstitüsü Gida Mühendisliği Anabilim Dalı Yüksek Lisans Tezi, Malatya.

Dağdelen, S., Bilenler, T., Durmaz, G., Gökbulut, I., Hayaloğlu, A.A., Karabulut, I. 2014. Volatile composition, antioxidant and antimicrobial activities of herbal plants used in the manufacture of Van Herby (Otlu) cheese. J Food Process Pres, 38: 1716-1725.

Delaquis, P.J., Stanich, K., Girard, B., Mazza, G. 2002. Antimicrobial activity of individual and mixed fractions of dill, cilantro, coriander and eucalyptus essential oils. Int I Food Microbiol, 74:101-109.

Dillard, C.D., German, J.B. 2000. Phytochemicals: Nutraceutical and human health. J. Sci. Food Agric, 80:1744-1756.

Durmaz, H., Sağun, E., Tarakçı, Z., Özgökçe, F. 2006. Antibacterial activities of Allium vineale, Chaerophyllum macropodum and Prangos ferulacea. Afr J Biotechnol, 5 (19): 1795-1798.

Durmaz, H., Aygün, O., Sancak, H., Çelik, H. 2015. Oxidant/antioxidant status of herbs Allium vineale and Chaerophyllum macropodum used for manufacture of Van herby cheese. IJSER, 1(1): 288-296.

Ebrahimabadi, A. H., Djafari-Bidgoli, Z., Mazoochi, A., Kashi, F. J., Batooli, H. 2010. Essential oils composition, antioxidant and antimicrobial activity of the leaves and flowers of Chaerophyllum macropodum Boiss. Food Control, 21:1173-1178.

Eloff, J.N. 1998. Which extractant should be used for the screening and isolation of antimicrobial components from plants? J Ethnopharmacol, 60: 18.

Ertekin Filiz, B., Seydim, A. C. 2014. Bazı Kurutulmuş Meyvelerin Antioksidan Özellikleri. Turk. Tarim Gida Bilim Teknol. Derg, 2(3):128-131. 
Griffin S. G., Wyllie, S. G., Markham J. L., Leach, D.N. 1999. The role of structure and molecular properties of terpenoides in determining their antimicrobial activitiy. Flavour Fragr J, 14: 322-32.

Katalinic, V., Milos, M., Kulisic, T., Jukic, M. 2006. Screening of 70 medicinal plant extracts for antioxidant capacity and total phenols. Food Chem, 94:550-557.

Kavaz, A., Bakırc1, İ., Kaban, G., 2013. Some physico-chemical properties and organic acid profiles of herby cheeses. Kafkas Univ Vet Fak Derg, 19(1):89-95.

Köse, S. 2015. Otlu peynire katılan bazı otların peynirin antimikrobiyal özellikleri, antioksidan kapasitesi ve fenolik bileşikleri üzerine etkisi. Yüzüncü Yıl Üniversitesi Fen Bilimleri Enstitüsü Gıda Mühendisliği Anabilim Dalı Doktora Tezi, Van.

Lin, J., Opoku, A. R., Geheeb-Keller, M., Hutchings, A.D., Terblanche, S.E., Jäger, A. K., Van Staden, J. 1999. Preliminary screening of some traditional Zulu medicinal plants for antiinflammatory and anti-microbial activities. $J$ Ethnopharmacol, 68: 267-274.

Najja, H., Zerria, K., Fattouch, S., Ammar, E., Neffati, M. 2011. Antioxidant and antimicrobial activities of Allium Roseum L. "Lazoul,"A wild edible endemic species in North Africa. Int J Food Prop, 14: 371-380.

NCCLS (National Committee for Clinical Laboratory Standard), 1999. Performance Standards for Antimicrobial Susceptibility Testing. 9th International Supplement. M100-S9, Wayne Pa.

Ocak, E., Tunçtürk, Y., Javidipour, I., Köse, Ş. 2015. Farklı Süt Türlerinden Üretilen Van Otlu Peynirlerinde Olgunlaşma Boyunca Meydana Gelen Değişiklikler: Mikrobiyolojik Değişiklikler,
Lipoliz ve Serbest Yağ Asitleri. YYU Tar Bil Derg, 25(2): 164-173.

Ojala, T., Remes, S., Haansuu, P., Vuorela, H., Hiltunen, R., Haahtela, K., Vuorela, P. 2000. Antimicrobial activity of some coumarin containing herbal plants growing in Finland. $J$ Ethnopharmacol, 73: 299-305.

Re, R., Pellegrini, N., Proteggente, A., Pannala, A., Yang, M., Rice-Evans, C. 1999. Antioxidant activity applying an improved ABTS radical cation decolorization assay. Free Radic. Biol. Med, 26: 1231-1237.

Rice-Evans, C., Miller, N., Paganga, G. 1996. Structure-antioxidant activity relationships of flavonoids and phenolic acids. Free Radic. Biol. Med, 20: 933-956.

Sağun, E., Durmaz, H., Sancak, H. 2005. Otlu peynir üretiminde kullanilan otların mikrobiyolojik ve kimyasal nitelikleri. YYU Sağhlk Bilimleri Dergisi, 8(1-2): 33-38.

Sağun, E., Durmaz, H., Tarakçı, Z., Sağdıç, O. 2006. Antibacterial activities of the extracts of some herbs used in Turkish herby cheese against Listeria Monocytogenes Serovars. Int J Food Prop, 9: 255-260.

SAS Institute Inc. 2012. SAS Version 9.3 Cary, NC, USA.

Yemis O., Bakkalbasi E., Artık, N. 2008. Antioxidant activities of grape (Vitis vinifera) seed extracts obtained from different varieties grown in Turkey. Int J Food Sci Technol, 43:154-159. 